\title{
The Effect of Foreign Direct Investment on Industrial Sector Growth: Evidence from Sri Lanka
}

\author{
NPG Samantha (Corresponding author) \\ School of Economics \\ Huazhong University of Science and Technology \\ P.R. China \\ E-mail: samanthanpg@yahoo.com
}

Haiyun Liu

School of Economics

Huazhong University of Science and Technology

P.R. China

Received: June 29, $2018 \quad$ Accepted: July 31, $2018 \quad$ Published: August 9, 2018
doi:10.5296/jad.v4i2.13339 URL: https://doi.org/10.5296/jad.v4i2.13339

\begin{abstract}
The development of the industrial sector stimulates economic growth and development by reducing poverty and regional disparity, increasing export income, generating quality employment, as well as developing technological capabilities and productive capacities. It has been more than four decades since removing trade-related barriers, and tax incentives liberalized the Sri Lankan economy offered to foreign investors to attract FDI and promote the industrial sector. Hence, the objective of this study is to investigate the relationship between inward FDI and industrial sector performance of Sri Lanka at the aggregate level for the period 1980-2016. We use the Auto Regressive Distributed Lag (ARDL) model to identify the long-run relationship and short-run dynamics of the selected variables. ARDL bounds test verifies the existence of co-integration among the selected variables. The study fails to find a significant relationship between FDI and industrial sector growth of Sri Lanka in the long run as well as in the short run. The attraction of vertically integrated FDI that consists with advanced technology and value-added production is one of the solutions for overcoming the issue of low technology and knowledge of Sri Lankan industrial sector. Sri Lankan FDI strategy associated with industrial sector should consider the pull and push factors related to recipient and source country respectively. To promote the industrial sector
\end{abstract}


via FDI, the government policy should focus on attracting more FDI that could be channeled into those sectors that would contribute to national competitiveness.

Keywords: Foreign direct investment, Industrial sector, Economic growth, Vertical FDI

\section{Introduction}

Foreign direct investment (FDI) is considered as a vehicle that transfers stable funds, technology and skills from developed economies to developing economies (Borensztein, De Gregorio, \& Lee, 1998). FDI is essential in attracting more technological innovations, skills, and spillovers for the development of the industrial sector in developing countries. It will enhance the industrial base of the nation by increasing resource endowments and changing the structure of the economy. According to Rodríguez-Clare (1996), the variety of specific inputs and the relative strength of the competition determine the impact of FDI on the domestic industrial sector. FDI effect on the industry is twofold: the linkage effect and the competition effect. Linkage effect on industrial sector of host country occurs when the production of investing foreign firms depends on intermediate goods produced by local firms. Because of product competition, foreign firms may force domestic firms to exit the market. Rapid economic growth in the South East Asian region with higher FDI in industrial sector witnessed the positive impact of FDI on economic growth. The improvement in the industrial sector is vital for developing countries like Sri Lanka where labor productivity in the primary sector is relatively low. Hence, the marginal productivity of labor will increase with the release of workers from the agricultural sector to the industrial sector.

Sri Lanka is a small open economy in the South Asian Region with US\$ 87.2 billion GDP and 21.44 million populations. Sri Lanka as an independent state since 1948, has achieved substantial development, despite a recent past marked by nearly thirty years of internal conflict, which was ended in 2009. The country has shown tremendous progress in poverty reduction and human development ranking 73 out of 188 countries in the Human Development Index (HDI). Furthermore, it is in the high human development category and ranks $4^{\text {th }}$ among 29 developing and emerging Asian countries in the HDI (UNDP, 2016). Sri Lanka recorded about 5.8 percent annual economic growth since 1990 showing long-term stable growth. Regarding per capita income, the country marked the highest value in the south Asian Region and upgraded to the lower middle-income category in 2010. However, the country is facing macroeconomic challenges at present. The progress recorded in previous decades is at risk in the medium term due to weak signs of some macroeconomic fundamentals. Firstly, the low level of government revenues is a limitation in annual budget implementation that creates a structural budget deficit raising the level of public debt. Secondly, a sharp depreciation of the national currency and a reduction of foreign exchange reserves generate external pressure. Despite these economic challenges, the country has to deal with some social issues such as aging of population and labor market challenges, and migration of young graduates.

In 1978, Sri Lanka introduced a comprehensive package of trade liberalization as the very first country in the South Asian region. The prime objective of the policy changes was private 
sector-driven economic growth, FDI promotion, and export lead growth. Since the economic liberalization, the country implemented numerous economic policies to stimulate industrial sector performance. The establishment of the Export Development Board in 1978 and export processing zones, privatization of state industrial undertakings are some examples of such attempts (CBSL, 2016). The development of the industrial sector will support economic growth and development by reducing poverty and regional disparity, increasing export income, generating quality employment, as well as developing technological capabilities and productive capacities. It has been more than four decades since removing trade-related barriers, and tax incentives liberalized the Sri Lankan economy offered to foreign investors to attract FDI and promote the industrial sector. Hence, the objective of this study is to investigate the relationship between inward FDI and industrial sector performance of Sri Lanka at the aggregate level for the period 1980-2016. The findings of the study will provide a direction to government officials and policymakers on how to manage macroeconomic variables and economic policies to promote the industrial sector through FDI. Further, the findings could be used as an example for other developing countries with similar economic characteristics to Sri Lanka.

The rest of the paper will be as follows. The following section discusses the available literature related to the study. In part three, we develop the methodology and empirical model. Estimated results and discussion are presented in section four. Section five concludes the paper.

\section{Literature Review}

The relationship between FDI and economic growth has extensively been discussed in the economic literature. It is evidence of the advantage that can be achieved through FDI, which includes stable funds, advanced technology, and management skills to stimulate economic growth and development. During the 1990's, the boom of newly industrialized countries in South East Asia witnessed rapid economic growth with high inward FDI. The same strategy followed by the countries like Argentina, Brazil, and Poland. African countries are relatively shown low economic progress with low inward FDI.

Theoretically, FDI stimulates host country industrial growth by transferring technology and restructuring industrial sector. Generally, Multinational Co-operations (MNC) or foreign firms are technologically advanced than local firms when investing in the host country. Technology transfer takes place when local firms adapt MNC's or foreign firm's technology. The existing competition of the host country may affect in the presence of affiliates of MNC's or foreign firms. In such a situation, the industrial structure of the host country may change or restructure to compete with MNC's. According to Dunning \& Lundan (2008), this spillover effect arises as a direct consequence of linkages between FDI and host country economic agents.

In the neoclassical growth model, Solow (1957) emphasized the vital role of technological progress on economic growth. Furthermore, Solow decomposed economic growth into growth related different inputs. Based on Solow's model, Findlay (1978) developed a model 
which shows a positive relationship between FDI and economic growth. Further, he argued that inflows of FDI increase the rate of technological progress with advanced technology and methods. Based on endogenous growth models, Blomström and Kokko (2003) paid more attention to FDI spillover through technology and skills. According to them, to stimulate economic growth, FDI should increase similarly with educational progress and domestic investment. Then only employers would invest in technology, method, and knowledge.

Some micro and macro levels studies have been focused on the relationship between FDI and economic growth. Aitken and Harrison (1999) investigated the effect of FDI on more than 4000 domestic firms in Venezuela during 1976-1989. They have found a positive relationship between foreign equity participation and productivity in plants less than 50 employees. Furthermore, they have found an adverse effect of FDI on the productivity of wholly domestically owned firms. Also, they have suggested that the net impact of foreign ownership on the economy is quite small. They could not find any spillover effect from foreign firms to domestic firms. Conducting an influential study, Borensztein et al. (1998) stated FDI as a vehicle transferring technology from developed to developing countries. Furthermore, they found that the higher productivity of FDI depends on the level of human capital of the host county. The absorptive capacity of technology depends on the level of available technology of the host country. Hence, FDI contributes to economic growth only when the host country capable of absorbing advanced technology.

By analyzing the impact of FDI on host country economic growth, Agrawal (2015), Agrawal and Khan (2011), Iamsiraroj and Ulubaşoğlu (2015), Soltani and Ochi (2012) have found positive significant relationship while Akinlo (2004), Azman-Saini et al. (2010), Masry (2015) have found weak connection. Furthermore, Herzer et al. (2008) challenged the common belief of the positive impact of FDI on economic growth. By analyzing data from 28 countries, he could not find any effect of FDI on economic growth in many of the nations.

Despite analyzing the impact of FDI on host country economic growth in aggregate level, few studies have been focused on identifying the effects of FDI in sector level. In an influential study, Chakraborty and Nunnenkamp (2008) analyzed the impact of FDI on economic growth as a whole and sector level for the time series data of India. The study found a significant causal relationship between FDI stock and manufacturing sector output and failed to find any causal relationship in the primary sector. Services sector FDI found as a growth promoter in the manufacturing sector through cross-sector spillovers. They confirmed the argument that the impact of FDI on economic growth does not depend only on the amount of FDI but also on its structural composition and type. Masron and Hassan (2016) investigated the impact of US FDI on the manufacturing sector of Malaysia for the period from 1999 to 2008. The study could not find positive spillover from FDI inflows to various industries in the manufacturing industry. By using Cobb-Douglas production function, Suleman and Amin (2015) found a positive and significant effect of the sectoral foreign direct investment on the industrial economic growth of Pakistan. Umer and Alam (2013) analyzed the impact of FDI and trade openness on industrial sector performance of Pakistan under the VECM framework. The study confirmed the common belief of the positive effects of FDI on 
industrial sector growth. Further, they suggest an increase of FDI and gross capital formation to stimulate industrial sector growth.

According to the available literature, the impact of FDI on economic growth or industrial sector performance depends on country-specific characteristics. This study is an attempt to study the impact of inward FDI on industrial sector performance of Sri Lanka for the period from 1980 to 2016 . The findings of the study would provide policy guidance for the better performance of the industrial sector of Sri Lanka.

\section{Methodology}

This section describes the methods used in this paper. Specifically, it covers the theoretical framework, model specification, estimation strategy, data and description of the variable.

\subsection{Theoretical Framework and Model Specification}

The conceptual framework of the study begins with the neoclassical growth model. The neoclassical growth model is considered to be the most vital starting point in growth economics. This model can describe the growth process by using two equations: the production equation and the capital accumulation equation. The production equation of the neoclassical model expresses the current flow of output goods as a function of the existing stock of capital and labor.

$$
Y=A K^{\alpha} L^{1-\alpha}
$$

Where $A$ represents a productivity parameter and $\alpha$ is less than one $(\alpha<1)$. Hence, production encompasses decreasing returns to capital. Capital accumulation depends on investment and depreciation of capital.

$$
\dot{K}=s Y-\delta K
$$

Where $s Y$ is the aggregate savings and $\delta K$ is the aggregate depreciation of capital. Aggregate savings is equal to aggregate investment. According to the neoclassical growth model, to achieve long-run economic growth, the productivity $A$ also should grow over time. Solow (1956) refers to this as technological progress, but the concept cannot be explained or rationalized within the neoclassical growth model. There was a need for a theoretical framework in which productivity growth is endogenous to analyze policies of growth. Endogenous growth models overcome this issue by assuming productivity growth to be endogenous. With the objective of capturing the impact of inward FDI on the output of the Sri Lankan industrial sector, this study uses an $A K$ type production function.

$$
Y_{t}=A_{t} K_{t}^{\alpha}
$$

Where $Y, K$, and $A$ are the country's output, capital and productivity parameters at time $t$, respectively. To examine the effect of FDI and trade openness on industrial sector growth in Sri Lanka, we apply a model derived from an endogenous growth model as follows.

$$
Y i s_{t}=f\left(A F d i_{t}^{\beta_{1}} G c f_{t}^{\beta_{2}} \operatorname{Top}_{t}^{\beta_{3}} C p i_{t}^{\beta_{4}} e_{t}^{\mu_{t}}\right)
$$


By taking logarithms of all the selected variables, we transform a nonlinear function into a linear function as follows

$$
\ln Y i s_{t}=\ln A+\beta_{1} \ln F d i_{t}+\beta_{2} \ln G c f_{t}+\beta_{3} \ln T o p_{t}+\beta_{4} \ln C p i_{t}+\mu_{t}
$$

Where $A$ is the productivity parameter, Yis is the industrial sector value added in time $t, F d i$ is the inward foreign direct investment in time $t, G c f$ is the gross capital formation in time $t$, Top is the trade openness in time $t, C p i$ is the consumer price index in time $t$ and $e$ is the error term.

Based on the Equation 5, taking technology as constant, the log-linear specification of the empirical model is developed as below:

$$
\ln Y i s_{t}=\beta_{0}+\beta_{1} \ln F d i_{t}+\beta_{2} \ln G c f_{t}+\beta_{3} \ln T o p_{t}+\beta_{4} \ln C p i_{t}+\mu_{t}
$$

Where $\beta_{0}$ is the intercept, and "ln" represents the natural logarithms. The coefficients of the selected variables that we are going to examine are indicated by $\beta_{1}-\beta_{4}$.

\subsection{Data Sources and Variable Description}

We obtained the data used in this study from the World Development Indicators of the World Bank. The data period covered from 1980 to 2016. We use the value added of the Sri Lankan industrial sector (Yis) based on the price level of 2010 as the dependent variable. We include the percentage of inward FDI to GDP as an independent variable into the selected model to identify the short-run dynamics and long-run relationship between FDI and industrial sector performance of Sri Lanka. According to the economic literature, the relationship between FDI and economic growth is ambiguous. Some researchers have found significant positive association (Agrawal, 2015; Bengoa \& Sanchez-Robles, 2003; Fedderke \& Romm, 2006; Hansen \& Rand, 2006) between FDI and host country economic growth while some others have found weak or insignificant relationship (Belloumi, 2014; Haruna Danja, 2012; Masry, 2015). Hence, the sign and the level of significance of the coefficient of FDI with industrial sector performance have to be tested empirically in the Sri Lankan context.

We use the real value of annual gross capital formation (Gcf) based on the 2010 price level as a proxy for capital accumulation. The study expects a positive relationship between capital accumulation and industrial sector performance of Sri Lanka. Trade openness is formulated as the percentage value of the summation of total trade (Exports + Imports) to the GDP for a specific period, generally a year. The relationship between trade openness and industrial growth can be positive or negative depending on country-specific characteristics. For instance, Sakyi et al. (2015) have found a positive long-run relationship while Umer and Alam (2013) have found a negative long-run relationship between economic growth and trade openness. Consumer price index represents the changes of the general price level of the economy over a period. We use the value of consumer price index taking 2010 as the base year. The relationship between inflation and economic growth is also a debatable issue. According to Fischer (1993) inflation is a growth demoting factor which results in reducing investment and output. The other argument is that one-digit inflation is favorable for economic growth while two-digit inflation leads towards sluggish growth. By conducting a co-integration analysis for 
selected South Asian countries namely Bangladesh, India, Pakistan, and Sri Lanka, Mallik and Chowdhury (2001) have found a positive relationship between these two variables. Hence, we expect a positive coefficient between industrial sector growth and the consumer price index. Depending on the above discussion, the summary of the anticipated signs of the factors is $\beta_{1} \lessgtr 0, \beta_{2}>0, \beta_{3} \lessgtr 0, \beta_{4}>0$.

\subsection{Estimation Strategy}

\subsubsection{Unit Root Test}

The objective of undertaking a stationary test is to determine the order of integration of all the variables under consideration. If the mean and variance of a time series parameter are infinite and independent of time while its co-variance is finite and independent of time, such a variable is said to be stationary. In contrast, a variable is supposed to be nonstationary if the mean and variance of a time series parameter vary over time. Before applying any co-integration analysis, it is essential to test the stationarity properties of the selected variables; otherwise, regression analysis will yield spurious results in the presence of nonstationary data. The Augmented Dickey-Fuller (ADF) test advocated by Dickey and Fuller (1981) is the most common test to check the order of integration of time series variables. The following equation (Eq. 7) presents the ADF unit root test.

$$
\Delta Y_{t}=\emptyset_{1}+\emptyset_{2}+\delta y_{t-1}+\sum_{i=1}^{m} \emptyset_{3} \Delta Y_{t-1}+\varepsilon_{t}
$$

Where $\varepsilon$ is an error term.

\subsubsection{ARDL Approach and Co-Integration}

In the co-integration analysis, the selection of an appropriate technique depends on the level of integration of the selected time series variables. If the variables are integrated at different levels, conventional co-integration tests cannot be applied. However, the Auto Regression Distributed Lag (ARDL) model advocated by Pesaran, Shin, and Smith ( 2001) overcome this issue and can be applied to the variables integrated at $\mathrm{I}(0)$ and $\mathrm{I}(1)$. However, any of the variables should not be stationary at I(2) to apply the ARDL model. The ARDL equation used in this study is given below.

$$
\begin{aligned}
\Delta \ln Y i s_{t}= & \beta_{0}+\beta_{1} \operatorname{lnYis}_{t-1}+\beta_{2} \ln f d i_{t-1}+\beta_{3} \operatorname{lnG} c f_{t-1}+ \\
& \beta_{4} \operatorname{lnTop}_{t-1}+\beta_{5} \ln C p i_{t-1}+\sum_{i=1}^{n} \beta_{6 i} \Delta \ln Y i s_{t-1}+ \\
& \sum_{i=1}^{n} \beta_{7 i} \Delta \ln F d i_{t-1}+\sum_{i=1}^{n} \beta_{8 i} \Delta \ln G c f_{t-1}+ \\
& \sum_{i=1}^{n} \beta_{9 i} \Delta \operatorname{lnTop}_{t-1}+\sum_{i=1}^{n} \beta_{10 i} \Delta \ln C p i_{t-1}+\mu_{t}
\end{aligned}
$$

Where $\beta_{0}$ is the intercept, $\mu_{t}$ is the error term, $\beta_{1}$ to $\beta_{5}$ represent the long-run elasticities, and $\beta_{6}$ to $\beta_{10}$ are the short-run dynamics. The sign $\Delta$ indicates the differenced operator. The appropriate lag length is determined by using the Akaike Information Criterion (AIC). The presence of a long-run relationship among the variables is verified using the ARDL 
bound test. The null hypothesis of no long-run relationship of the bound test is $\left(\beta_{1}=\beta_{2}=\right.$ $\beta_{3}=\beta_{4}=\beta_{5}=0$ ). In contrast, the alternative hypothesis of the long-run relationship between the variables of the selected model is $\left(\beta_{1} \neq 0, \beta_{2} \neq 0, \beta_{3} \neq 0, \beta_{4} \neq 0, \beta_{5} \neq 0\right)$. The acceptance of the alternative hypothesis depends on the critical values of the Pesaran table. Pesaran et al. (2001) have formulated upper and lower critical values to test the co-integration among the variables. If the estimated F-statistic of the bound test is higher than the upper critical value, we can reject the null hypothesis accepting the alternative of co-integration. On the other hand, the null hypothesis is accepted if the estimated F-statistics value is lower than the lower critical value. The result is inconclusive if the estimated value of F-statistics remains between two critical values.

If the modeled variables are co-integrated, then we can explore the short-run relationship by applying the Error Correction Model (ECM) developed by Engle and Granger (1987). The ECM version of the ARDL model is specified as follows.

$$
\begin{aligned}
\Delta \ln Y i s_{t}= & \sum_{i=1}^{n} \beta_{1 i} \Delta \ln Y i s_{t-1}+\sum_{i=1}^{n} \beta_{2 i} \Delta \ln F d i_{t-1} \\
& +\sum_{i=1}^{n} \beta_{3 i} \Delta \ln G c f_{t-1}+\sum_{i=1}^{n} \beta_{4 i} \Delta \ln T o p_{t-1} \\
& +\sum_{i=1}^{n} \beta_{5 i} \Delta \ln C p i_{t-1}+\lambda E c t_{t-1}+\mu_{t}
\end{aligned}
$$

Where Ect and $\lambda$ represent error term and speed of adjustment parameter respectively.

\section{Results and Discussion}

\subsection{Unit Root Test}

The stationarity results of ADF test are presented in Table 1. Accordingly, only the variable inward foreign direct investment (lnFdi) is stationary at level. Hence, it can be considered as an $\mathrm{I}(0)$ series. The rest of the variables, real value added in the industrial sector (lnYis), the real value of gross capital formation $(\operatorname{lnGcf})$, trade openness $(\ln T o p)$ and consumer price index (lnCpi) turn into stationary at first difference. Hence, they can be considered as I(1) series. Since variables are stable at different levels I(0) and I(1), we can apply the ARDL co-integration model advocated by Pesaran et al. (2001).

\subsection{ARDL Regression Analysis}

The estimated regression results of the Equation 8 using the ARDL model developed by Pesaran et al. ( 2001) are presented in Table 2. We follow the Akaike Information Criterion (AIC) in ARDL regression analysis with the maximum lag length of four for both dependent and independent variables. Eviews 10 software is used to run ARDL regression. The selected lag lengths of the variables of the model are $(4,0,1,1,0)$.

The probability of F-statistic is highly significant indicating the overall performance of the 
industrial sector of Sri Lanka more sensitive to local shocks than external shocks. A $1 \%$ increase in gross capital formation will lead the industrial sector by $0.33 \%$ in the long run. FDI is found to be an insignificant factor in explaining industrial sector value added in the long term as well as in short-term for Sri Lanka. The relationship between consumer price index and industrial sector growth is positive and significant showing that $1 \%$ increase in consumer price index stimulates industrial sector growth by $0.38 \%$. Furthermore, trade openness is found to be an insignificant factor in explaining the long-run growth of the industrial sector of Sri Lanka.

Table 2. ARDL regression results

\begin{tabular}{|c|c|c|c|}
\hline Variable & Coefficient & t - Statistics & Probability \\
\hline $\operatorname{lnYis}_{\mathrm{t}-1}$ & 0.8481 & 5.7694 & $0.0000^{*}$ \\
\hline $\operatorname{lnYis} \mathrm{t}_{-2}$ & 0.0151 & 0.0839 & 0.9338 \\
\hline $\operatorname{lnYis}_{t-3}$ & -0.0312 & -0.1735 & 0.8636 \\
\hline $\operatorname{lnYis} \mathrm{s}_{\mathrm{t}-4}$ & -0.1688 & -1.3502 & 0.1907 \\
\hline $\operatorname{lnFdi} i_{t}$ & 0.0015 & 0.2152 & 0.8316 \\
\hline $\operatorname{lnGcf_{t}}$ & 0.2019 & 5.4198 & $0.0000^{*}$ \\
\hline $\operatorname{lnGcf} f_{t-1}$ & -0.0895 & -2.2592 & $0.0341 * *$ \\
\hline $\operatorname{lnTop} \mathrm{p}_{\mathrm{t}}$ & 0.1382 & 3.2145 & $0.0040^{*}$ \\
\hline $\operatorname{lnTop}_{\mathrm{t}-1}$ & -0.0974 & -2.5414 & $0.0186 * *$ \\
\hline $\operatorname{lnCpi_{t}}$ & 0.1287 & 3.7121 & $0.0012^{*}$ \\
\hline Constant & 4.4954 & 4.0223 & $0.0006^{*}$ \\
\hline
\end{tabular}

R - squared : 0.96

Adjusted R- squared: 0.96

F - stat : 52.31

Probability of F-stat: 0.0000

Durbin-Watson Stat: 2.1835

Akaike Info Criterion: -5.5337

Schwarz Criterion: -5.0349

Hannan - Quinn Criterion: -5.3659

ARDL(4,0,1,1,0

Note: $*$ and $* *$ denote significant at $1 \%$ and $5 \%$ level respectively

Source: Own study 
Table 3. ARDL Bound test results

Computed F - statistics: 7.3769

\begin{tabular}{lll}
\hline Critical value & Lower bound value & Upper bound value \\
$1 \%$ & 4.093 & 5.532 \\
$5 \%$ & 2.947 & 4.088 \\
$10 \%$ & 2.46 & 3.46 \\
\hline
\end{tabular}

Source: Own study

Short-run dynamics of the variables of the model are also presented in Table 4. Gross capital formation and trade openness are found to be significant variables in explaining industrial sector growth in the short run. The coefficient of the error term (Ect-1) is negative and significant indicating the convergence of short-run shocks to long-run equilibrium. The value of the speed of adjustment parameter is 33\% meaning that approximately three years period is required to adjust back short-run shocks into long-run equilibrium path.

Table 4. Short run and long-run results

\begin{tabular}{llll}
\hline Long run elasticities & & & \\
\hline Variables & Coefficient & t- statistics & Probability \\
Constant & 13.3479 & 8.4276 & $0.0000^{*}$ \\
$\operatorname{lnFdi}_{\mathrm{t}}$ & 0.0046 & 0.2112 & 0.8346 \\
$\operatorname{lnGcf_{\mathrm {t}}}$ & 0.3337 & 5.4806 & $0.0000^{*}$ \\
$\ln \mathrm{nop}_{\mathrm{t}}$ & 0.1211 & 1.4538 & 0.1601 \\
$\operatorname{lnCpi}_{\mathrm{t}}$ & 0.3822 & 11.1457 & $0.0000^{*}$ \\
Short-run elasticities and error correction model & & \\
$\Delta \operatorname{lnYis}_{\mathrm{t}-1}$ & 0.1849 & 2.0402 & $0.0535^{* * *}$ \\
$\Delta \operatorname{lnYis}_{\mathrm{t}-2}$ & 0.2001 & 2.0999 & $0.0474^{* *}$ \\
$\Delta \operatorname{lnYis}_{\mathrm{t}-3}$ & 0.1688 & 2.0724 & $0.0501^{* * *}$ \\
$\Delta \operatorname{lnGcf}_{\mathrm{t}}$ & 0.2019 & 8.4869 & $0.0000^{*}$ \\
$\Delta \operatorname{lnTop}_{\mathrm{t}}$ & 0.1382 & 4.5149 & $0.0002^{*}$ \\
Ect $_{(\mathrm{t}-\mathrm{l})}$ & -0.3367 & -7.3703 & $0.0000^{*}$ \\
\hline
\end{tabular}


R - squared : 0.78

Adjusted R- squared: 0.74

Durbin - Watson Stat: 2.1835

Akaike Info Criterion: -5.8368

Schwarz Criterion: -5.5647

Hannan - Quinn Criterion: -5.7452

$\operatorname{ARDL}(4,0,1,1,0)$

Source: Own study.

\subsection{Diagnostic and Stability Test}

Table 5 shows the results of all the diagnostic tests that we conduct to verify the normality of residuals and stability of the model. The results of the Jarque-Bera statistics confirm the normal distribution of error term. Furthermore, the results of Table 5 prove that the model is free from serial correlation, heteroscedasticity, and auto-correlation. Results of Ramsey test assure the stability of the parameters of the model. Furthermore, we test the stability of the model by using CUSUM and CUSUM square tests. As shown in Figure 1, both CUSUM and CUSUMSQ strips lie within the 5\% critical range indicating model stability.

\subsection{Causality Test}

We check short-run causality between the selected variables using the Granger causality test. Table 6 depicts the results of short-run causality test. Accordingly, bi-directional causality is found between industrial sector growth and domestic capital formation at $5 \%$ significant level. Unidirectional causality is found from consumer price index to industrial sector growth, FDI, and gross capital formation. No causality is seen running from FDI to any selected variables.

Table 5. Diagnostic test results

\begin{tabular}{lll}
\hline & F - Statistics & Probability \\
\hline$\chi^{2}$ NORM & 0.0850 & 0.9583 \\
$\chi^{2}$ RAMSEY & 0.5489 & 0.4670 \\
$\chi^{2}{ }_{\text {ARCH }}$ & 0.2970 & 0.5754 \\
$\chi^{2}$ Serial Correlation & 1.1022 & 0.1943 \\
\hline
\end{tabular}

Source: Own study. 


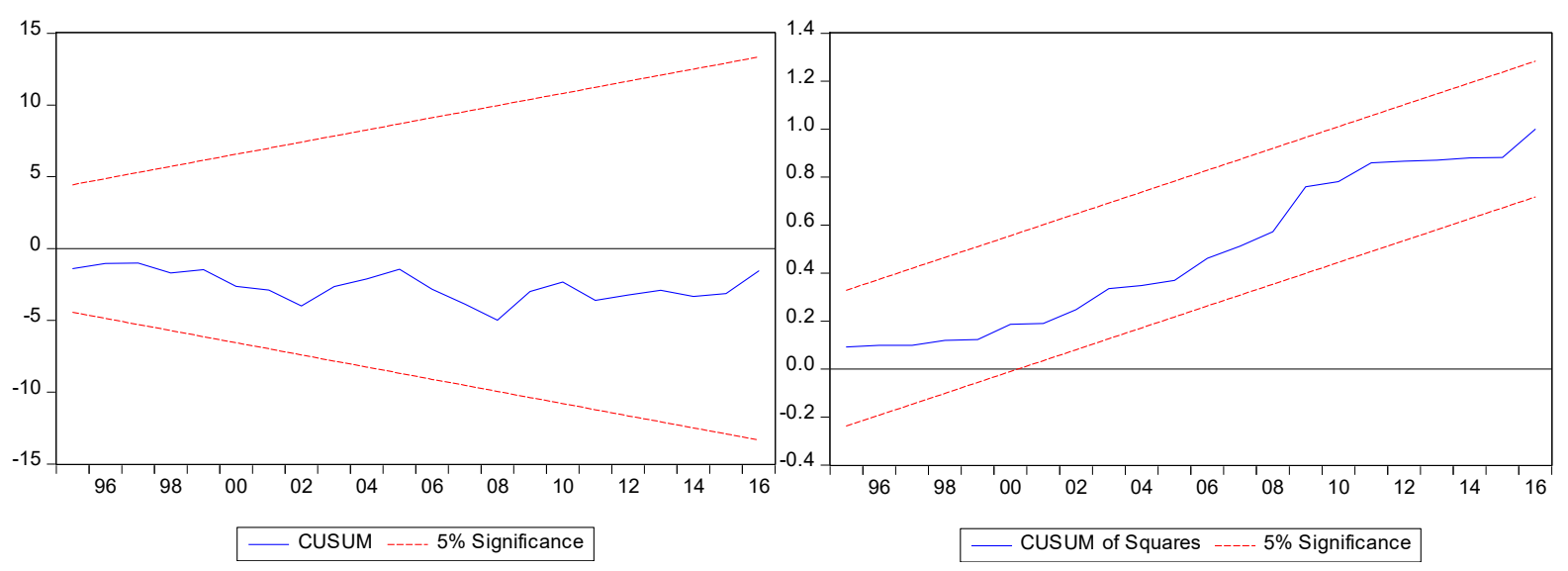

Figure 1. CUSUM and CUSUMSQ tests

Table 6. Results of Granger Causality test

\begin{tabular}{lllllll}
\hline Variables & Yis & Fdi & Gcf & Top & Cpi & Direction of causality \\
\hline Yis & - & $3.0501^{* * *}$ & $4.5236^{* *}$ & 0.5697 & 0.1109 & $\begin{array}{l}\text { Yis } \rightarrow \text { Fdi, } \\
\text { Yis } \rightarrow \text { Gcf }\end{array}$ \\
\hline Fdi & 0.5056 & - & 0.5510 & 2.4087 & 0.0142 & No causality \\
\hline Gcf & $3.1165^{* *}$ & 1.3883 & - & 2.4914 & 0.7433 & Gcf $\rightarrow$ Yis \\
\hline Top & 1.5343 & 0.1366 & 0.4454 & - & $2.9898^{* * *}$ & Top $\rightarrow$ Cpi, \\
\hline Cpi & $8.0220^{*}$ & $3.2989 * * *$ & $6.2105^{* *}$ & 0.4354 & - & Cpi $\rightarrow$ Yis, Cpi $\rightarrow$ Fdi, Cpi $\rightarrow$ Gcf
\end{tabular}

Note: $(*),(* *)$ and $(* * *)$ indicate rejection of no causality at $1 \%, 5 \%$ and $10 \%$ significant levels respectively

Source: Own study.

\subsection{Discussion}

The findings of the empirical study confirm an insignificant relationship between FDI and industrial sector performance of Sri Lanka for the period from 1980 to 2016. The results of the study are consistent the argument that the impact of FDI on economic growth depends on not only the overall size of FDI but also the type and structural composition (Chakraborty \& Nunnenkamp, 2008). Although Sri Lanka changed its economic policies to attract more FDI, the progress in inward FDI was not at the expected level compared to the neighboring countries, which had similar economic characteristics at the time of getting independence.

Many developing nations that shared comparable economic characteristics to Sri Lanka during the 1950s boost their production capabilities in the industrial sector by applying government lead policies with the objective of expanding manufacturing base exports in the mid- $20^{\text {th }}$ century. It is said that Asian countries followed a "flying geese pattern" lead by Japan and followed by South Korea, Singapore, Hong Kong, and Taiwan at initially and later 
on many other nations like China, Thailand, Malaysia and Indonesia. Latin American countries such as Chile, Mexico, Brazil, and Peru also followed the same strategy. The economic and social conditions of all these countries are higher than that of Sri Lanka at present. The economic structure of these countries first transformed from the agricultural base to the industrial sector and later on deepened the services sector. Sri Lanka's growth pattern was dissimilar from countries that developed through industrialization and has leap-frogged from an agricultural based economy to a service-based economy (CBSL, 2016). Table 7 shows the changing pattern of sectoral composition of Sri Lanka's GDP declining agriculture sector while increasing services sector.

Table 7. Sectoral composition of GDP - Sri Lanka

\begin{tabular}{llll}
\hline Year & Agriculture & Industry & Services \\
\hline 1950 & 46 & 20 & 37 \\
1960 & 38 & 17 & 45 \\
1970 & 28 & 24 & 48 \\
1978 & 26 & 24 & 50 \\
1980 & 24 & 24 & 52 \\
1985 & 26 & 26 & 49 \\
1990 & 23 & 27 & 50 \\
1995 & 20 & 30 & 50 \\
2000 & 19 & 28 & 53 \\
2005 & 17 & 27 & 56 \\
2010 & 12 & 29 & 59 \\
2015 & 8 & 27 & 57 \\
2016 & 7 & 27 & 57 \\
\hline 2017 & 7 & 27 & 57 \\
\hline
\end{tabular}

Source: Central Bank of Sri Lanka.

The type of FDI is vital for the development of the industrial sector, especially in the manufacturing sector that represents a significant share in the industrial sector of Sri Lanka. Attracting FDI is crucial for the development of the industrial sector to a country like Sri Lanka where characterized by low domestic savings and high budget deficits. The attraction of vertically integrated FDI that consists with advanced technology and value-added production is one of the solutions for overcoming the issue of low technology and knowledge of Sri Lankan industrial sector. Newly industrial countries in the East and South East Asian region accelerated their economic growth via attraction of vertically integrated FDI and 
entering into global value chains of production. Despite South East Asian countries, Sri Lanka's inward FDI consisted with market-seeking investment in the tourism and real estate sectors in the previous decades (Table 8).

Table 8. Sectoral composition of Inward FDI - Sri Lanka

\begin{tabular}{llllll}
\hline \multirow{2}{*}{ Sector } & \multicolumn{2}{l}{ Years } & & & \\
\cline { 2 - 6 } & $\mathbf{2 0 1 2}$ & $\mathbf{2 0 1 3}$ & $\mathbf{2 0 1 4}$ & $\mathbf{2 0 1 5}$ & $\mathbf{2 0 1 6}$ \\
\hline Manufacturing & 22.99 & 25.86 & 20.66 & 26.50 & 30.93 \\
- Textile, Wearing Apparel \& Leather & 6.48 & 3.57 & 5.14 & 4.68 & 6.17 \\
- Chemicals, Petroleum, Coal, Rubber\& Plastics & 4.42 & 8.22 & 5.69 & 7.78 & 12.43 \\
Agriculture & 0.54 & 0.61 & 0.35 & 0.40 & 0.24 \\
Infrastructure \& Services & 76.48 & 73.53 & 73.55 & 73.10 & 68.84 \\
Infrastructure & 44.58 & 56.55 & 42.22 & 46.76 & 42.38 \\
- Housing \& Property Development & 4.17 & 15.64 & 20.99 & 21.87 & 9.92 \\
$\quad$ Telephone \& Telecommunication Network & 18.09 & 25.86 & 9.43 & 14.32 & 30.41 \\
Services & 31.89 & 16.99 & 31.33 & 26.34 & 26.45 \\
- Hotels \& Restaurants & 8.77 & 4.88 & 4.23 & 18.76 & 17.64 \\
Total FDI & 1338.16 & 1391.41 & 1616.33 & 969.66 & 801.00 \\
\hline
\end{tabular}

Source: BOI- Sri Lanka.

Manufacturing sector oriented FDI that can contribute more to export performance was narrowly concentrated on a few labor-intensive, low-tech industries such as textiles, apparel, and leather. After the trade liberalization, Sri Lanka's export composition changed from primarily agricultural products to more value-added labor-intensive industrial products. However, the Sri Lankan export basket narrowly concentrated on two traditional products, tea, and garments, which accounted for more than half the export earnings. The export direction of Sri Lanka is also suffering from lack of market diversification as only a few markets are catered to, such as the USA and Europe, which accounted for nearly two-thirds of the total export earnings (CBSL, 2016).

Sri Lankan FDI strategy associated with industrial sector should consider the pull and push factors related to recipient and source country respectively. Cross-country empirical studies have found pull factors such as low-cost labor, competitive exchange rates, low tax regimes, raw material, access to markets, and the availability of land for setting up plants, etc. FDI decision of foreign firm depends on the host country's macroeconomic environment that facilitates pleasant investment surroundings such as political stability, quality of public 
institutions, efficient logistics, ample macroeconomic and legitimate structures, and trade openness, etc. Global value chains of production in its nature transport product components from one location to another location depending on the efficiency of production. Hence, the efficiency of logistics such as access to ports, sea and road transports, customs clearance, low levels of tariff and non-tariff barriers and warehousing are vital. Especially the FDI originating from emerging economies such as China, Russia, Malaysia, and India are more concern on the quality of infrastructure than did firms of advanced economies in the past (CBSL, 2016).

Whether there was a spillover effect from foreign firms to local firms in promoting exports in the Sri Lankan context is questionable though. The internal conflict, from which Sri Lanka suffered for nearly three-decades, increased the political risk and uncertainty, and macroeconomic instability. Vertically integrated assembly industries are more sensitive to political risks than those producing light consumer goods. Hence, the country missed the opportunity for attracting vertically integrated assembly industries that could have contributed much to export performance (Athukorala and Jayasuriya, 2004).

\section{Conclusion and Recommendation}

The prime objective of this study was to examine the effect of FDI on industrial sector performance of Sri Lanka for the period from 1980 to 2016. In doing so, we applied the ARDL co-integration technique developed by Pesaran et al. (2001). The selected variables for the model were real value added in the industrial sector, the percentage of FDI to GDP, trade openness, gross capital formation and consumer price index. Data were extracted from the World Development Indicators of the World Bank. We used the ADF unit root test to check the order of integration of the selected variables. Since the variables were stationary at different levels I(0) and I(1), we applied the ARDL test for co-integration analysis. ARDL bounds test verified the existence of co-integration among the selected variables rejecting the null hypothesis of no co-integration $\left(\beta_{1}=\beta_{2}=\beta_{3}=\beta_{4}=\beta_{5}=0\right)$ at $1 \%$ level. In the long run, only gross capital formation and consumer price index were statistically significant in explaining the variance of industrial sector value added in Sri Lanka. It realized that the industrial sector of Sri Lanka more sensitive to local shocks than external shocks. FDI and trade openness were found to be an insignificant factor in explaining industrial sector value added in the long run. In the short run, gross capital formation and trade openness were found to be significant variables in explaining industrial sector growth. The coefficient of the error term (Ectt-1) was negative and significant indicating the convergence of short-run shocks to long-run equilibrium. The value of the speed of adjustment parameter was $33 \%$ meaning that approximately three years period would be required to adjust back short-run shocks into long-run equilibrium path. Results on Sri Lanka are consistent with the cross-country findings in which the growth effects of FDI depend on several factors such as local skills and absorptive capacity, linkages between foreign and domestic firms and technological spillovers, and export orientation.

The attraction of vertically integrated FDI that consists with advanced technology and value-added production is one of the solutions to overcome the issue of low technology and 
knowledge of Sri Lankan industrial sector. Political risks and macroeconomic uncertainty prevailing in Sri Lanka would hinder the chances of attracting vertically integrated assembly industries, which can have a significant impact on manufacturing sector growth and export performance. Sri Lankan FDI strategy associated with industrial sector should consider the pull and push factors related to recipient and source country respectively. The government policy should focus on attracting more FDI that could be channeled into those sectors that would contribute to national competitiveness to promote the industrial sector via FDI.

\section{References}

Agrawal, G. (2015). Foreign Direct Investment and Economic Growth in BRICS Economies: A Panel Data Analysis. Journal of Economics, Business, and Management, 3(4), 421-424. https://doi.org/10.7763/JOEBM.2015.V3.221

Agrawal, G., \& Khan, M. A. (2011). Impact of FDI on GDP: A Comparative Study of China and India. International Journal of Business and Management, 6(10), 71-79. https://doi.org/10.5539/ijbm.v6n10p71

Aitken, B. J., \& Harrison, E. (1999). Do Domestic Firms Benefit from Direct Foreign Investment? Evidence from Venezuela. The American Economic Review, 89, 605-618. https://doi.org/10.1257/aer.89.3.605

Akinlo, A. E. (2004). Foreign direct investment and growth in Nigeria. An empirical investigation. Journal of Policy Modeling, 26(5), 627-639. https://doi.org/10.1016/j.jpolmod.2004.04.011

Athukorala, P., \& Jayasuriya, S. (2004). Complementarity of Trade and FDI Liberalization in Industrial Growth: Lessons from Sri Lanka. In 10 Years of ASARC an International Conference, Common Room, University House, ANU, Canberra, Australia, 27 \& 28 April 2004.

Azman-Saini, W. N. W., Baharumshah, A. Z., \& Law, S. H. (2010). Foreign direct investment, economic freedom, and economic growth: International evidence. Economic Modelling, 27(5), 1079-1089. https://doi.org/10.1016/j.econmod.2010.04.001

Belloumi, M. (2014). The relationship between trade, FDI and economic growth in Tunisia: An application of the autoregressive distributed lag model. Economic Systems, 38(2), 269-287. https://doi.org/10.1016/j.ecosys.2013.09.002

Bengoa, M., \& Sanchez-Robles, B. (2003). Foreign direct investment, economic freedom, and growth: New evidence from Latin America. European Journal of Political Economy, 19(3), 529-545. https://doi.org/10.1016/S0176-2680(03)00011-9

Blomström, M., \& Kokko, A. (2003). The Economics of Foreign Direct Investment Incentives (NBER Working paper series No. 9489). Cambridge. Retrieved from http://www.nber.org/papers/w9489\%0A

Borensztein, E., De Gregorio, J., \& Lee, J.-W. (1998). How does foreign direct investment 
affect economic growth? Journal of International Economics, 45(1), 115-135. https://doi.org/10.1016/S0022-1996(97)00033-0

CBSL. (2016). Annual Report 2016, Central Bank of Sri Lanka. Colombo, Sri Lanka.

Chakraborty, C., \& Nunnenkamp, P. (2008). Economic Reforms, FDI, and Economic Growth in India: A Sector Level Analysis. World Development, 36(7), 1192-1212. https://doi.org/10.1016/j.worlddev.2007.06.014

Dickey, B. Y. D. A., \& Fuller, W. A. (1981). Likelihood Ratio Statistics for Autoregressive Time Series with a Unit Root. Econometrica, 49(4), 1057-1072. https://doi.org/10.2307/1912517

Dunning, J. H., \& Lundan, S. M. (2008). Multinational Enterprises and the Global Economy (2nd Editio). Edward Elgar Publishing Limited.

Engle, R. F., \& Granger, C. W. J. (1987). Co-integration and error correction:representation,estimation and testing. Econometrica, 55, 251-276. https://doi.org/10.2307/1913236

Fedderke, J. W., \& Romm, A. T. (2006). Growth impact and determinants of foreign direct investment into South Africa, 1956-2003. Economic Modelling, 23(5), 738-760. https://doi.org/10.1016/j.econmod.2005.10.005

Findlay, R. (1978). Relative Backwardness, Direct Foreign Investment, and the Transfer of Technology: A Simple Dynamic Model. The Quarterly Journal of Economics, 92(1), 1-16. https://doi.org/10.2307/1885996

Fischer, S. (1993). The role of Macroeconomic Factors in growth. Journal of Monetary Economics, 32, 485-512. https://doi.org/10.1016/0304-3932(93)90027-D

Hansen, H., \& Rand, J. (2006). On the causal links between FDI and growth in developing countries. World Economy, 29(1), 21-41. https://doi.org/10.1111/j.1467-9701.2006.00756.x

Haruna Danja, K. (2012). Foreign Direct Investment and the Nigerian Economy. American Journal of Economics, 2(3), 33-40. https://doi.org/10.5923/j.economics.20120203.02

Herzer, D., Klasen, S., \& Nowak-Lehmann D., F. (2008). In search of FDI-led growth in developing countries: The way forward. Economic Modelling, 25(5), 793-810. https://doi.org/10.1016/j.econmod.2007.11.005

Iamsiraroj, S., \& Ulubaşoğlu, M. A. (2015). Foreign direct investment and economic growth: A real relationship or wishful thinking? Economic Modelling, 51, 200-213. https://doi.org/10.1016/j.econmod.2015.08.009

Mallik, G., \& Chowdhury, A. (2001). Inflation and Economic Growth: Evidence from Four South Asian Countries. Asia Pacific Development Journal, 8(1), 123-135.

Masron, T. A., \& Hassan, M. K. (2016). US Foreign Direct Investment (FDI) and Manufacturing Sector in Malaysia. Asian Academy of Management Journal, 21(1), 89-110. 
Masry, M. (2015). Does Foreign Direct Investment (FDI) Really Matter in Developing Countries? The Case of Egypt. Research in World Economy, 6(4), 64-77. https://doi.org/10.5430/rwe.v6n4p64

Pesaran, M. H., Shin, Y., \& Smith, R. J. (2001). Bounds testing approaches to the analysis of level relationships. Journal of Applied Econometrics, 16(3), 289-326. https://doi.org/10.1002/jae.616

Rodríguez-Clare, A. (1996). Multinationals, Linkages, and Economic Development. The American Economic Review, 86(4), 852-873.

Sakyi, D., Commodore, R., \& Opoku, E. E. O. (2015). Foreign Direct Investment, Trade Openness and Economic Growth in Ghana: An Empirical Investigation. Journal of African Business, 16(1-2), 1-15. https://doi.org/10.1080/15228916.2015.1061283

Solow, R. M. (1956). A Contribution to the Theory of Economic Growth. The Quarterly Journal of Economics, 70(1), 65-94. https://doi.org/10.2307/1884513

Solow, R. M. (1957). Technical Change and the Aggregate Production Function. The Review of Economics and Statistics, 39(3), 312-320. https://doi.org/10.2307/1926047

Soltani, H., \& Ochi, A. (2012). Foreign Direct Investment (FDI) and Economic Growth: an approach in terms of cointegration for the case of Tunisia. Journal of Applied Finance \& Banking, 2(4), 193-207.

Suleman, M. T., \& Amin, M. T. (2015). The Impact of Sectoral Foreign Direct Investment on Industrial Economic Growth of Pakistan. Journal of Management Sciences, 2(1), 151-165. https://doi.org/10.20547/jms.2014.1502101

Umer, F., \& Alam, S. (2013). Effect of Openness to Trade and FDI on Industrial Sector Growth: A Case Study for Pakistan. The Romanian Economic Journal, XVI(48), 179-198.

UNDP. (2016). Human Development Report 2016 Human Development for Everyone. New York: United Nations Development Programme. https://doi.org/10.18356/e525b80e-en

\section{Copyright Disclaimer}

Copyright for this article is retained by the author(s), with first publication rights granted to the journal.

This is an open-access article distributed under the terms and conditions of the Creative Commons Attribution license (http://creativecommons.org/licenses/by/4.0/). 